\title{
XIX. A report of the progress of phytochemistry in the year 1835, in reference to the physiology of plants
}

\section{J.Cl. Marquart}

To cite this article: J.Cl. Marquart (1837) XIX. A report of the progress of phytochemistry in the year 1835, in reference to the physiology of plants, Philosophical Magazine Series 3, 11:66, 156-166, DOI: $10.1080 / 14786443708649250$

To link to this article: http://dx.doi.org/10.1080/14786443708649250

曲 Published online: 01 Jun 2009.

Submit your article to this journal $[\pi$

Џll Article views: 2

Q View related articles $₫$ 
hence the following composition:

$$
\begin{aligned}
& 1 \text { Sugar ............. }=171=46.72 \\
& 2 \mathrm{CaO}+2 \mathrm{HO} \ldots . . .=74=20.22 \\
& \underline{\mathrm{PlO}+\mathrm{HO}} \cdots \cdots \cdots=\frac{121}{366}=\frac{33.06}{100 .}
\end{aligned}
$$

Baryta and Strontia Saccharates.-By agitating a syrup with either of the hydrates of these earths, and then with the oxides of copper, iron, or lead, we obtain solutions which behave very much the same as the calcareous saccharates.

Potassa and Soda Saccharates.-When either of the fixed alkalies are united with sugar in their atomic proportions, we obtain solutions which dissolve the hydrated oxides, but which triple solutions continue soluble at $212^{\circ}$, though a further addition of free sugar causes a precipitation of protoxide when the solution of copper is heated.

Loftus near Guisborough, May 21, 1837.

Louis Hunton.

XIX. A Report of the Progress of Phytochemistry in the year 1835, in reference to the Physiolory of Plants. By J. Cu. MarQUart.*

$$
\text { [Continued from vol. x. p. 252.] }
$$

1

EX AMINED with M. F. Nees von Esenbeck t the bloom of the fruit of Benincasa cerifera, which consisted mostly of a whitish wax (66 per cent.), of resin ( 29 per cent.), and of extractive matter ( 5 per cent.). The first possessed the same properties with regard to solvents as vegetable wax; but was remarkable particularly on account of its high melting point, viz. at $100-120^{\circ}$ Reaum. We found as a discriminating character for this wax, by which it may be distinguished fron the numerous resins of difficult solution, its reaction with sulphuric acid in the cold, as it is scarcely coloured by it, or not at all if the wax is very pure. We examined in regard to this the so-called Japanese wax of Rhus succedanea, the wax of Corypha cerifera, and the wax from the seed-lac of Aleurites laccifera, which corresponded with the bloom of the Benincasa. According to Boussingault the composition of the wax-like envelope of Ceroxylon andicola, which entirely covers that palm, often reaching to the height of fifty feet, is the same

* From Wiegmann's Archiv fiir Naturgeschichte, vol, ii. part iv, p. 139 ct seq. 'Translated by Mr. Fiancis.

† Buchin. Rispert., vol. li. part 3.

- Antules de Chimic el de lhysiques, May 1835. 
as that of the bloom of the fruit of this Cucurbitaceous plant. The wax of this envelope melts, however, at a much lower temperature, even below $80^{\circ}$ Reaum., is little coloured, resembles bees' wax, and has the same elementary composition.

M. Mulder found in the husk or rind of coloured fruits, as those of Pyrus Malus, Capsicum annum, Sorbus aucuparia, Cucurbita Lagenaria, invariably combined with the colouring matter, a wax which was alway's found to be a pure cerin *. By the experiment before mentioned, M. Du Menil obtained from the bark of Pinus sylvestris also 13 per $M$. of a whitish wax, the nature of which was not more exactly determined $\uparrow$.

M. Fr. Nees von Esenbeck and the author examined the milk-sap of several fig treest, in order to find whether the Lacca in granis could originate from trees of this genus, as is said, but must declare it to be erroneous; and they were induced to consider, as the only plant producing this remarkable vegetable body, the Aleurites lacciferu, which belongs to a family the chemical constitution of which allows us to infer the presence of similar resins to that which is contained in seed-lac.

At the same time they examined the milk-sap of Ficus elastica from the stem as well as from the young branches; and arrived at the result that the milk-sap of the young branches consists of resin, gum, wax, together with some extractive natter, a salt of lime, and a glutinous resin which was only soluble in ather, not in alcohol, and which they believed to be identical with the substance found by Macaire in Atractylis gummifera, and named by him Viscin $\$$. The milk-sap of the old stem contained, on the contrary, caoutchouc instead of viscin, and also the other constituent parts of the milk-sap of the young branches, which is only observable when the milksap is allowed to flow immediately into the ather. If it coagulates in the air, traces only of resin, gum, and extractive matter can be separated from the mass which has become caoutchouc or elastic resin (Feder harz). The milk-saps of many other species of this genus contained viscin, but in a few cases only had it become cauntchouc in the old stems. M. Zeller \| found this viscin also in the berries of Sambucus Ebulus. Without doubt the seed-lac (lacca in granis) belongs to the coagulated milk-saps which have been drawn from the branches of Aleurites laccifera? by some peculiar lac Aphis. I ex-

* Bydragen tot de naturkundige Wetenshappen, d. vii. No. ¿.

+ Archive für Pharmacic, vol. i. part 1.

\$ Amale'n dor Pharmacic, vol. xiv. part 1.

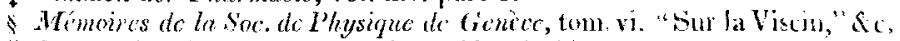

i) Wiirtcmbergisches Corresponilcnacnolall 1834. 
amined it more recently with Fr. Nees von Esenbeck* and found as its contents a peculiar wax which melts at $48^{\circ}$ Reaum., and also a series of peculiar resins. The substance called the insoluble lac-resin (lac of John) must be considered as representing the caoutchouc in this milk-sap, which resists the common solvents, and is only affected by acidulated alcohol. Nearly related to this is the Beta-resin of the lac, which part the authors consider as insoluble in ether and weak alcohol, and only sol uble in absolute alcohol, or that of $90^{\circ}$. By certain manipulations it passes over into the lac of John, and it may well be supposed that it owes its solubility in alcohol to the so-called lac acid which is mixed with it, the nature of which the authors were not able to ascertain on account of its rare occurrence. That part of the seed-lac which is soluble in spirits of wine and xther the authors named the Alpha-resin of the lac, and found the same to be again composed of the first alpha-resin, which is havd, friable, of a gold colour, and which gives with alkalies and oxides of lead beantiful purple red combinations, while the second alpha-resin is a yellow soft resin, and has in a very great degree the peculiar smell of shell-lac.

Scarcely any section of the vegetable formative parts is in greater want of a revision than that of the resins, whose diffusion is so general, and whose varieties almost keep pace with or appear even to surpass, the number of species of plants. We are convinced that a rational examination of this part of phytochemistry would give quite different results. In no analysis does there ever fail to be a resin among the educts enumerated; even in Sphcerococcus crispus M. Herberger found two different ones, which however, as in many other analyses, are so dubiously characterized, that we may here pass them over in silence without keeping anything important from our readers. Not cven is a consistent division followed in the description of these bodies; and it is probable that various nixed and changed substances are frequently cited as peculiar resins. We will therefore in this place only mention a few crystallizing resins, like that which $\mathrm{M}$. Landerert separated from the Resina Gugjaci nativa, which crystallizes in fine needles, void of smell, soluble in æether and boiling alcohol, and became by concentrated nitric acid of a lively grass green colour, and whose spirituous solution had acid reaction. A similar resin was found by Geiger in the bark of the root of Cornus florida, the solution of which, however, possessed neither an acid nor an alkaline reaction. In general, those resins which are not very

* Ciciger and Liebig's Ann. dor Pharm., vol. xiii. part 3.

+ Buchn. Repert., ,ii. 1.93. 
easily dissolved in alcohol are considered as sub-resins, with two of which we are already acquainted as possessing a crystalline nature, those from the Elemi and Euphorbiun, which are isomeric or have the same elementary composition, and consist of $2\left(\mathrm{C}_{10} \mathrm{H}_{16}\right)+\mathrm{O}^{*}$. The resin discovered by Boussingault in the wax-like covering of Ceroxylon andicola before cited, possesses a similar fundamental composition; it was of a bright white colour and crystalline, melts at above $100^{\circ}$ centig., is soluble in rther, xthereal oils, and alcohol. Nees von Esenbeck and the author found also in the bloom of the Benincasa fruit a white crystalline resin soluble in alcohol, and of a bitterish taste.

Th. Martius $\uparrow$ showed some time back how to prepare, free from colour, the brown resin from the jalap root, by treating the spirituous solution with animal charcoal; according to his nore recent experiments this decolorated resin, having been wrapped in paper, resumed after three years its brown colour. This colouring process appears in the course of time to change the resin in the root to the state in which we receive it; as according to the experiments of Nees von Esenbeck and the author, mentioned in last year's report (p. 220), the resin which had been extracted from jalap roots cultivated in Germany, and preserved only a short time, was scarcely coloured yeliow.

During the past year chemists have directed their attention particularly to the athereal oils of the black mustard-seed, and were occupied partly on methods of preparing it, as MM. Hesse ${ }_{+}^{+}$, Hoffmann $\S$, Fauré $\|$, Wittstock $q$, and Aschoff***. According to most of the observers, a great quantity of xthereal oil may be obtained from the meal of the black mustard-seed when it has been left for some time in cold water; from which it appears that, as in bitter alnonds, not the xthereal oil but the radical is contained in the seed. Faure observed that tincture of galls and chlorine prevented the evolution of the oil ; and Aschoff found that by mixing the mustard meal with water ammonia was evolved. The produce amounted in general to $0.9-1$ per cent. of a colourless oil, which is heavier than water $=1.002$ at $14^{\circ}$ Reaum. It is of the class of those containing sulphur, and does not explode with iodine; it does however with potassium. Ammonia combines with it, and torns

* Poggendorff's Annalen, vol. xxxiii. p. 49.

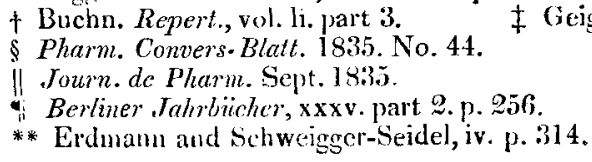


a substance which has much resemblance to Sulpho-sinapisin.

Bitter almonds and the leaves of the common laurel, from which is obtained an æethereal oil containing a great quantity of prussic acid, but which does not exist as such in the plants, exhibit similar characters. This part of phytochemistry has received, by Liebig and Wöhler's discovery of organic radicals, a direction the influence of which on many doctrines of physiology we have yet to await. We will here only mention as an instance the recent experiments of $M$. Winckler* on the products by distillation of bitter almonds and the leaves of the common laurel, and briefly remark that the æthereal oil of these bodies is a combination of benzoyl (the radical consisting of $\mathrm{C}_{14} \mathrm{H}_{5} \mathrm{O}_{3}$ ) with hydrogen; at the same time with this benzoyl hydruretted an evolution of a cyan-benzoyl takes place on distillation, which is the cause of the oil of bitter almonds containing prussic acid, and which may be separated

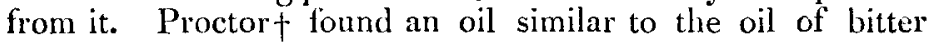
almonds in the bark of Prumus virginiana.

M. Pagenstecher t extracted from the flowers of Spirca Ulmaria a very remarkable æethereal oil, heavier than water, of a yellow colour, and of a peculiar smell similar to prussic acid. Its peculiar constitution is evident from the property of its spirituous solution, which becomes of a cherry-red colour when mixed with chloride of iron. Caustic alkalies form with it yellow combinations, in consequence of a peculiar acid which accompanies the oil, and by which it is connected with valerian oil, cinnamon oil, and the heavy oil of pinks. M. Löwig $\$$ examined the oil further, and regards it as the combination of spiroil (a radical of $\mathrm{C}_{12} \mathrm{H}_{10} \mathrm{O}_{4}$ ) with $2 \mathrm{M}$. G. hydrogen, but the spiroilic acid as the combination of spiroil with 4 M. G. oxygen. The Spircea oil solidifies at $-20^{\circ}$ and boils at $+85^{\circ}$.

Several æthereal oils were prepared and closely examined; one from the fruit of Coriandrum sativum by 'Trommsdorff"|; it was colourless, and the spec. grav. was 0.859. M. Bley 9 analysed the plant, flowers, and truit of Achillea nobilis. 'The athereal oils from the plant and the seeds were alike, of spec. grav. 0.970 , and of a butter-like consistence; that however from the flowers was of a thin liquid consistence, and spec.

* Buchn. Repert., vol. lii. p. 289.

‡ Buchn. Repert., vol. ix. p. 337 .

$\S$ Poggendorff's Annalen, vol. xxvi. p. 383 ; and Scientific Memoirs, vol. i. p. 153

If Archiv fiur die Pharmarie, ii. p. 113.

- Archiv fir die Pharmacie, vol. i. ii. iii. 
grav. 0.983. All three did not fulminate with iodine. It is astonishing that the oils from the fruit and the flowers did not coincide more, since it is certain that in the distillation of the flowers M. Bley did not separate the grermen. We therefore doubt the correctness of the statements, as in other respects the experiments of M. Bley have been conducted rather carelessly, which has been lately proved by all the analyses of Achillea nobilis. M. Landerer* prepared from the green part of Conium maculatum a small quantity of athereal oil, in obtaining which no one had before succeeded in Germany. Does the hemlock which grows in southerw latitudes (in Greece) form an exception?

James Martin † obtained from the leaves of Cassia marylandica also an æthereal oil, as did Zeller $\ddagger$ from the perisperm of Abies pectinata. The latter was limpid, spec. grav. $=0.839$; fulminated with iodine, but left potassium unchanged; it therefore contained no oxygen. The iethereal oil from the leaves of Myrica Gale $\$$ solidifies, according to Rabenhorst, at $14^{\circ}$ Reaum., and is at $15^{\circ}$ a thickish dark yellow mass, which contains 70 per cent. of stearoptin. It does not fulminate with iodine, and has a spec. grav. $=0.876$.

Elementary analyses have conducted us in the xthereal oils to very interesting results, and have made known to us, besides those oils accompanied by acids and sulphur and which have been mentioned above, a series of oils containing no oxygen, therefore containing only carbon and hydrogen; and another series containing carbon, hydrogen, and oxygen. To the first series belongs the oil of turpentine, consisting of $\mathrm{C}_{5} \mathrm{H}_{8}$; and the oil of the black pepper, the juniper oil, the savin oil, and according to Dumas $\|$ the oil of the fruits of Citrus medica and Citrus limetia have been found to be isomeric with it. In addition to these, posssesing the same combinations, are the light parts of the oils of pink and valerian, which on their separation were also accompanied by a peculiar acid : further, the copaiva balsam oil, the hasis of the cajeput oil, and of the turpentine-camphor; the cajeput oil is a hydrate, whose base, like that of the turpentine oil, consists of $\mathrm{C}_{5} \mathrm{H}_{8}$ : the turpentine-oil-camphor is another hydrate of this turpentine oil, which often separates itself from it in crystals. Colophony, copaiva resin, camphor, the caryophylline and lavendel-stearoptin have been acknowledged to be oxides

* Buchn. Repert., vol. iii. part 1.

+ The American Joum. of Pharuı, 1835. April.

$\$$ Archiv für Tharm., vol. iii.

$\$$ Berliner Jahrbiiche', vol. xxxv. part 2. p. 256 .

If Journ. de Chim. Méd., June 1838.

Third Serirs. Vol. 11. No.66. Aug. 1837. 


\section{J. C. Marquart's Report of the Progress of Plytochemistry}

of turpentine oil. The camphor oxide obtained by the distil-. lation of the roots of Iris florentina, and which is crystalline, laminated, and of a pearly lustre, consists of $\mathrm{C}_{4} \mathrm{H}_{8} \mathrm{O}$, and is therefore to be regarded as an oxide of oil of roses, $\mathrm{C}_{4} \mathrm{H}_{8}$. Till now the attempt to isolate the odorous principle from several strongly and agreeably smelling flowers has proved unsuccessful. Among these is the Narcissus Jonquilla, which Robiquet* examined, and from which, by extraction with sulphuric æther, he obtained a yellow æthereal oil, which is very volatile, and when once volatilized is not easily condensed. It decomposes very easily, even in closed vessels; it becomes solid, and then scarcely melts at $100^{\circ}$ centigr. and is a warty mass void of smell, which separated itself already with the rthereal oil, after evaporation of the cethereal extract. M. Herberger $\uparrow$ obtained from the flowers of Convallaria majalis a small quantity of a camphor-like substance, in part of a radiated crystalline structure and possessing a very strong smell.

What was formerly considered as benzoic acid in the flowers of Melilotus is, according to Guillemettet, similar to the substance from the tonquin bean which has been named Coumarine, and De Candolle mentions it in his Physiology (p. 352, Paris, 1832) under the hyperhydrogenic substances. It belongs rather, according to our views, to the camphoroids, on account of its volatility; it crystallizes, melts, volatilizes, dissolves in boiling water, in alcohol and ather. According to Heury, coumarine from the tonquin bean, as also from the Melilotus, consists of $\mathrm{C}_{5} \mathrm{H}_{6} \mathrm{O}_{9}$.

We have in general very little to remark on the fat oils, and confine ourselves to the relation of their occurrence in various plants, according to the observations of last year.

M. Trommsdorff found $\$$ in the fruit of Coriandrum sationum 13 per cent. of a fat oil insoluble in alcohol. It was void of smell, grayish green, thickish, and was easily decomposed into almost equal parts of stearine and elaine. J. Martin|| found in the leaves of Cassia marylandica a yellow fat oil, and a similar oil was found by Ch. Schreeveq in the bark of the root of Gillenia trifoliata. Semmola** determined the contents of the white fat oil in the tubers of the root of Cyperus csculentus to be 48 per $\mathrm{m}$., and Fleuron found fat oil in the roots of Astragalus escapus; M. Zenneck found in his analysis of the fruit

* Journ. de Pharm., July 1835.

+ Buchn. Repert. vol. lii.

\$ Archiv fïr Pharm., ii. 2.

† Joum. de Pharm. April 1835.

II The American Journ. of Pharm. April, 1835. I Ilid.

** Journ. de Chim. Méd. 1834. 
of Panicum miliaceum* 4.37 per cent. of a green fat oil, 2 per cent. of which was contained in the pericarp, and 2.37 per cent. in the albuminous body. Millet, therefore, in this respect surpasses the oat and rice.

Th. Martius $\uparrow$ found in the seeds of Strychnos Nux vomica 0.5 per cent. of an oil soluble in alcohol. The fat from the seeds of the East Indian species of Bassia, B.latifolia, butyrea, longifolia, of the family of the Sapotece, which belongs also here, is, according to C. Henry t, of a dirty yellow colour, and possesses an aromatic taste and smell. M. Koene extracted from the roots of Anacyclus Pyrethrum $\S$ two fat oils, one of which was soluble in oil of turpentine and alcohol, the other not. In the above-mentioned investigation of the flowers of $\mathrm{Nar}$ cissus Jonquilla M. Robiquet also found an oil of some consistency belonging to this division, smelling something like fishblubber. The albuminous body of Abies pectinata contains, according to Zeller\|, a drying oil, soluble in alcohol, whose spec. grav. was 0.913 ; and $M$. W urzer found in the same organ of Pinus pinea a fat oil, void of smell, and which did not dry up . J. Cockburn also found in the bark of the root of Cormus florid $a^{* * *}$ a fat oil soluble in alcohol and in wether.

The acids are a class of vegetable substances which are as widely diffused as the resins; they have however occupied the attention of chemists more than the latter, so that we are scarcely able to give more than the newly-discovered occurrence of the most important acids in individual plants. Among others, gallic acid was found by M. Aschoff't in the leaves of Rhas 'Toxicodendron; by Cockburntt in the bark of the roots of Cornus florida; by Joh. Tilhgmamn $\delta \delta$ in the roots of $\mathrm{Ci}$ micifuga racenosa, and by Proctor in the bark of Prunus virginiana.

It was formerly believed that the process of the formation of mould increased the quantity of gallic acid, whence it might be inferred that this acid was a product; the experiments of Winckler IIfi are opposed to this, although Aschoff states that he found a far greater quantity of gallic acid in the mouldy extract of the leaves of Toxicodendron than in the fresh sap.

* Buchn. lieperl., vol. Ixix.

$\ddagger$ Journ. de Pharm., Oct. 1835.

$\$$ Ann. de Chint. et de Phys., July 1835.

of Buchn. Repert., vol. xlix. p. 303.

* The American Jomru of Pharm., July 1835.

th Archio fiir Plourm. vol i. parts.

t+ 'The Anerican Jomrn. of Pharm., July 1835.

$\$ \$$ Jomn. de Ghim. Méd. 1834 . November.

IIf Buchn, licpert., vol. li.
+ Ibid, vol. li. prart iii.

|| Archiv für Pharm., vol. iii. 


\section{J.C. Marquart's Report of the Progress of Phytochemistry}

The peculiar substance of the Catechu prepared from the Nauclea Gambir is, as confirmed by Plaff*, identical with the tannic acid of Büchner. It dissolves easily in boiling water, less so in cold; the solution acts as an acid, becomes yellow when exposed to the air, colours solutions of iron green, and does not precipitate gelatine: it consists of $\mathrm{C}_{18} \mathrm{H}_{8} \mathrm{O}_{8}$.

The peculiar acid fumar acid, discovered by Winckler in Fumaria officinalis was subjected by Horace Demarcay to an elementary analysis, and was found to be isomeric with the paramalic acid, which, as is known, is a product of the decomposition of malic acid.

M. Geiger found in the bark from the roots of Cormus florida, an acid, cornic acid, which contained no nitrogen, was crystalline, easily soluble in water and alcohol, and possessed a bitter taste. 'The shiller substance (Shillerstoff') found in the bark of several dicotyledonous trees was more accurately examined by M. 'Trommsdorff, sen. + : its properties indicate that it belongs to the class of acids. Trommsdorff, jun., found it to consist of $\mathrm{C}_{8} \mathrm{H}_{9} \mathrm{O}_{5}$.

M.Trommsdorff, jun. $\oint_{\text {, found in the so-called wormseed }}$ (the fruit-bearing calathia of Artemisia glomerata, pure acetic acid; and M. Radig\| found 11 per cent. of acetic acid combined with potasin in the leaves of Digitalis propurea. M. Bley affirms that he found in the herbaceous part as well as in the flowers and seed of Achilled nobilis acetic acid containing formic acid; we lave however reason to doubt the truth of this. We have alroaly mentioned in speaking of the athereal oils the acid from the flowers of Spiraa Ulmaria.

M. H.Trommslorfl * lately examined the sylvic acid found in the resins of pines, and which was formerly considered, without any reason, as an oxide of oil of turpentine; according to M. Trommsdorft it is rather the oxide of a radical of $\mathbf{C}_{10}$ $\mathrm{H}_{15}$. It crystallizes in large colourless rhomboidal tables, and melts at $120^{\circ}$ Reaum. M. Liebig, who examined the other part of the colophony resin, the pinic acid, found it to lave the same composition, by which the isomery of both has again been confirmed.

M. Voget found +1 in the dried leaves of Asperula odorata

* Pfuff's Mithlilungen aus dem Gebicte der Pharm., etc. vol. i. part 3,4.

+ Ann. de Chim . et de Plyysique, August 1835.

† Geiger and Liebig's dinn. der Pharm., vol. xiv. part 2.

$\$$ Annalen der Pharmecic, vol. xi. part 2.

II Pharm. Novellen vou Ehrmann, 1834, part 2.

I Brand, Archiv fid. Plicum., vol. i, ii, and iii.

* Creiger and Liebig's Ann. der Pharm., vol. xiii.

it Archiv jür Plearm., vol. iii. 
benzoic acid; and M. Landerer* extracted from the roots of Inula Helenium scales similar to sebacic acid, which possessed a pearly lustre, were soluble only in wher and caustic potash, and devoid of smell and taste; the solution acted as an acid. Dumas describes a similar crystalline formation, which could be seen with the naked eye in the form of warty excrescences in the interior of the above-mentioned root $\uparrow$, which consisted of $\mathrm{C}_{7} \mathrm{H}_{9} \mathrm{O}$.

Prussic acid was found by Proctor in the bark of Prunus virginiana, and by $O$. Henry $\$$ in the sap of the root of Jatropha Manihot, or at least, as in most cases, a radical from which it might be formed.

Between these azotic acids and the alkaloids must be placed, on account of their containing nitrogen a division of vegetable formative parts, which for this reason have been termed indifferent, and among which many substances too little known have been classed: the following however have found their right place. Emetine may, according to Landerer $\|$, be prepared in small white cubical crystals, the solution of which acts as an alkali and is precipitated by tincture of galls; it must for this reason take its place in the following division, the alkaloids. The nicroscopico-chemical experiments on the pollen by M. Fritsche have further shown that the Pollenin of authors deserves no place amongst the proper vegetable formative parts, being unaltered pollen, from the epidermis of which several soluble substances were extracted by means of various solvents, while the contents remained unchanged. He made his experiments with the pollen of Corylus Avellana. What was formerly described in this division under the name of Asparagin is, according to the experiments of MM. Wittstock, Regimbeau**, and Schmidt + , confirmed to be aspartate of ammonia, and is not contained as such in the roots of Althea officinalis, nor in the young sprouts of Asparagus officinalis or acutifolius, but is a product of decomposition. 'The latter found this salt in the sap of the leaves of Atropa belladonna which had been evaporated to consistence. The bitter substance from Cetraria islandica may be justly considered to belong to this division. Rigatelliț has described a method of preparing this new substance in cry-

* Buchn. Repert., vol. xlix. p. 275 .

$\uparrow$ Journ. de Chimie Mód. June 1835.

§ Journ. de Pham, 1834. Nov.

I Poggendorff, Annalen, vol. xxxii. n. 31.

+ Ibid., 1834.

* Jouru. de Pharmacie, 1834. November.

t† Annal. der Pharm., vol. xii.

¥t Goretta eclotl. di Farmacia, 1835. Nov. 11 et 12. 
stals, which dissolve in water and in alcohol, but not in æher', and the solutions of which are thrown down as a red precipitate by iron and its salts.

[To be continued.]

XX. Account of some Experiments made in different Parts of Europe, on Terrestrial Magnetic Intensity, particularly with reference to the Effect of Height. By James D. Furbes, Esq., F.R.SS. L. \& E., \& c., Professor of Natural Philosophy in the University of Edinburgh.

[Continued from p. 66, and concluded.]

18. V. Variations in the Needles' Magnetism.-In all observations of this kind, this change gives rise to the most troublesome errors. 'The mode of ensuring an equable magnetic state is unknown, though an approximation may generally be obtained to it. Of the two needles sent to this comntry in 1827, by Professor Hansteen, one (No. 1.) has, after some slight variations, become almost stationary in its magnetism; the other " Flat" has been continually dinimishing in intensity. We have seen in the last article that the earth's magnetic action, varying continually and being unknown, we can only properly compare observations made at the same time of the year, and of the day. The progress of change in the neediles may be traced by the following tables*.

TABLE IV.

\begin{tabular}{|c|c|c|c|c|}
\hline \multicolumn{5}{|c|}{ NEEDLE, No. 1.} \\
\hline l'hec. & Date. & Observer. & $\begin{array}{l}\text { Iog. Time } \\
\text { 3000 Viluations. }\end{array}$ & \begin{tabular}{|} 
Arg. Ratio of \\
AntulatChange
\end{tabular} \\
\hline $\begin{array}{l}\text { Makerstonn, } \\
\text { Edinbur.. } \\
\text {... } \\
\ldots . \\
\text {..... } \\
\text { Paris, . . } \\
\ldots . . .\end{array}$ & $\begin{array}{l}1899, \text { Jan. } 20,3^{\mathrm{h}} \\
1830, \text { Jan. } 23,3^{\mathrm{h}} \\
1899, \text { July } 9 ; 11^{\mathrm{h}} \\
1832, \text { June } 2,11^{\mathrm{h}} \\
1833 \text {, May } 7,5^{\mathrm{h}} \\
1835 \text {, May } 4,1^{\mathrm{h}} \\
1833 \text {, June } 11,1^{\mathrm{h}} \\
1835, \text { June } 13,4^{\mathrm{h}}\end{array}$ & $\begin{array}{c}\text { Dumlop. } \\
\ldots \ldots \\
\ldots \cdots \\
\text { Forbes. } \\
\cdots \\
\cdots \\
\ldots \\
\ldots\end{array}$ & $\left.\begin{array}{l}\left.\begin{array}{l}290251 \\
2 \cdot 90248\end{array}\right\} \\
2 \cdot 907651 \\
2 \cdot 90890 \\
290849 \\
2 \cdot 90915\} \\
2 \cdot 87102 \\
287092\end{array}\right\}$ & $\begin{array}{l}\cdot 99997 \\
\cdot 00043 \\
\cdot 99956 \\
\cdot 00066 \\
\cdot 99995\end{array}$ \\
\hline $\begin{array}{l}\text { The differcn } \\
\text { variations }\end{array}$ & $\begin{array}{l}\text { since June } 1832 \text { ar } \\
\text { e. }\end{array}$ & probal & imputable to & the horary \\
\hline
\end{tabular}

* The mutual action of the necdles is a peint of importarce. Before they canc into my posession they were kept in their scharate cascs, but without further attention, being packed together in the same external case 